\title{
Is your Brexit supply chain resilient enough? The British footwear manufacturers' perspective
}

Since the majority Brexit vote cast on 23 June 2016 (Economist, 2016), there is uncertainty among many businesses, and development projects have been put on hold.

According to Professor Frances Corner, Head of the London College of Fashion and pro vice-chancellor of the University of the Arts London (cited in McGregor, 2016), companies are reluctant to invest in ambitious business development projects due to the blow Brexit has dealt to business confidence.

That said, there is no time to lose. This chaotic uncertainty amongst many retailers is offering a unique opportunity to become a market leader in the new post-Brexit market.

"What I have learnt is never to panic and to adapt quickly. The reaction is more important than the issue" Federico Marchetti, Chief Executive of Yoox Net-a Porter Group (Porter, 2016).

\section{Consequences of Brexit}

Many UK retailers have been hit, even those advanced in development terms (Economist, 2016). So, what will happen to companies in sectors with the least advanced operations in the months to come?

Typically, the footwear industry is old-fashioned, with long lead times that need to be overcome. Relatively few of these companies have reaped the rewards of the simple practices propounded in supply chain literature, or replicated the strategies employed by market leaders.

Increased transit times, for example, both in and out of Britain, will almost certainly result from increased trading restrictions with detrimental effect on the entire industry. Upcoming post-Brexit challenges, when coupled with vulnerable supply chains may even wipe out businesses altogether, since it is commonly believed that after the UK's split with Europe, the market environment will separate into those companies which have been continuously working on improving their resilience and those who waited for that perfect moment to adapt.

In the context of existing challenges, the Brexit storm, with all its inevitable complexities, however daunting, can be weathered though, as when businesses are at their most flexible, strategic changes are the easiest to make.

It will be crucial to analyse entire supply chains to understand and surmount the issues ahead. Only by rebuilding existing supply chains from scratch will a company be able to establish true supply chain resilience. All available options should therefore be considered and proven successes built on.

Interestingly, despite the general feeling of inertia, a recent Barclays study encouragingly found that threequarters of UK e-commerce and multi-channel retailers are actively looking to build more efficient supply chains as a direct consequence of the Brexit vote, and are thinking very carefully about what they need to do now (Rigby, 2016). There are many potential improvements that retailers may be considering, but which will be the most effective, given the time frame?

Preparing for Post-Brexit reality 
Discussions regarding the effects of the split on UK fashion retailers are lengthy, but keeping all one's eggs in one basket certainly seems the riskiest option. Today's largely neglected supply chain segmentation practices can help overcome this challenging period of uncertainty and bring competitive advantage to the imminent new market.

The strategic aim of this article is to encourage small to mid-sized enterprises to enhance their existing supply chains in order to make it through and succeed in a new, post-Brexit environment. Furthermore, mention is made of the study conducted by Romans Safonovs (2015), which points towards major business restructure or the search for innovative ideas, irrespective of the size of the business or the resources that may be available at the time. This study analyses the operations of major fashion retailers, complete with business expert interviews and is backed up with first hand, up to date examples regarding British industry players. This one of a kind undertaking serves as a guide for industry players seeking ways in which to increase their competitiveness.

Safonovs (2015) extends the existing theory of supply chain segmentation and advocates an opportunity to revive European and British production. It focuses on the European non-athletic footwear industry with its significant interest in UK-based businesses, where lengthy lead times are particularly challenging. The project also puts forward a managers' 3-step guide to developing a few possible supply chain strategies, the main focus being on segmentation based on demand/supply predictability. Here we see the introduction of a new "trial agile pipeline" which supports responsive supply capability from a local site. Similarly, the report reviews pragmatic strategies matching supply and demand throughout the whole Product Life Cycle with a new order-winning criterion "Design and material grade".

\section{Comment}

At the time this research was conducted, findings demonstrated that insourcing opportunities and revived British manufacturing largely depends on the level of support that the government can offer to offset high investments and operational costs. Although the question is still open, current political and economic factors point towards investing in initiatives that could create more favorable conditions for local production and the supply chain strategies being suggested.

\section{References}

Economist (2016), "After the vote, chaos", 25 June, p.1.

McGregor, K. (2016), "UK Fashion and Brexit - A f28bn Industry Hangs In the Balance", available at: https://thestand.investec.co.uk/uk-fashion-brexit-28bn-industry-hangs-balance/ (accessed 12 December 2016). Porter, C. (2016), "After Brexit, which way for fashion?", available at: https://www.ft.com/content/8f288762-3316-11e6-bda0-04585c31b153 (accessed 15 December 2016). Rigby, C. (2016), "The Brexit effect on UK retailers - and their supply chains: study", available at: http://internetretailing.net/2016/08/brexit-effect-uk-retailers-supply-chains-study/ (accessed 09 October 2016). Safonovs, R. (2015) "Improving the competitiveness of the European non-athletic footwear industry through wellconsidered supply chain segmentation practices that could also give rise to renewed footwear production in Europe", MSc Thesis, Cranfield School of Management, UK. 


\section{About the author}

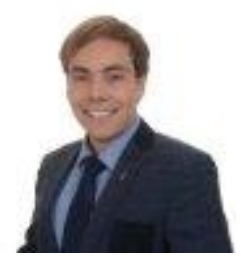

Roman is a Supply Management Executive at Coty Inc., with a previous experience working for apparel, footwear and accessory companies. Also Brighton Business School Alumni and holds an accredited MSc Logistics and Supply Chain Management degree from Cranfield School of Management.

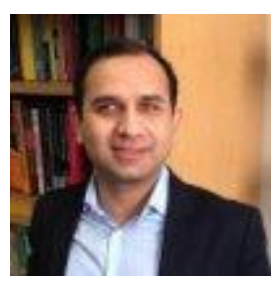

Dr Arvind Upadhyay is a Senior Lecturer in Logistics and Supply Chain Management at Brighton Business School of University of Brighton, UK. He completed his first Degree in Electrical Engineering and an MBA in New Delhi, India. His MSC degree in Strategic Project Management European was on European Commission's Erasmus Mundus Scholarship from Heriot-Watt University, Edinburgh, UK in collaboration with MIP Business School of Politecnico di Milano, Italy and Umea University, Sweden. He holds's a PhD in Logistics and Supply Chain Management from University of Bergamo, Italy in collaboration with SDA Bocconi and MIT-Zaragoza Logistics Centre, Spain. As a doctoral researcher, he spent one year at the Cambridge Judge Business School and King's College, University of Cambridge and at the Cranfield School of Management, UK. His varied research work is published in book chapters, case studies, academic journals and presented at International conferences. He is on the editorial and review committee board of various journals and is also a member of the Chartered Institute of Purchasing and Supply (CIPS), British Academy of Management (BAM), Production and Operations Management Society (POMS) and the European Operations Management Association (EurOMA). 